\title{
Perlindungan Hukum terhadap Hak Anak dalam Memperoleh Akta Kelahiran
}

\author{
Anak Agung Ketut Sukranatha ${ }^{1}$, Anak Agung Istri Ari Atu Dewi ${ }^{2}$
}

${ }^{1}$ Anak Agung Ketut Sukranatha; Fakultas Hukum Universitas Udayana; Jl. Pulau Bali No.1 Denpasar; 80114; (0361) 222666; Indonesia.

${ }^{2}$ Anak Agung Istri Ari Atu Dewi; Fakultas Hukum Universitas Udayana; Jl. Pulau Bali No.1 Denpasar; 80114; (0361) 222666; Indonesia.

\section{ART I C LEINFO}

Article history:

Received 2018-02-16

Received in revised form

2018-03-06

Accepted 2018-06-01

Kata kunci:

Perlindungan hukum, hak anak, akta kelahiran.

Keywords:

Legal protection, child rights, birth certificate.
Corresponding Author:

Anak Agung Ketut Sukranatha

E-mail address: agung_sukranatha@unud.ac.id DOI: https://doi.org/10.26905/idjch.v9i1.2160

\section{Abstrak}

Permasalahan anak akhir-akhir ini sangat kompleks. Banyak kasus-kasus yang terjadi di masyarakat yang mengabaikan pemenuhan hak anak. Salah satu adalah tidak terpenuhinya hak anak atas akta kelahiran. Berhubungan dengan hal tersebut maka penting dilakukan penelitian untuk mengetahui 2 (dua) hal yaitu; pertama, untuk mengetahui terhadap hak anak dalam mendapatkan akta kelahiran pada masyarakat adat Bali. Kedua, untukmengetahui Apakah seorang anak bisa mendapatkan akta kelahiran apabila pencatatan kelahirannya melampui batas waktu. Sesuai dengan tujuan penelitian, metode penelitian yang digunakan adalah metode penelitian normatif dengan pendekatan peraturan peundang-undangan (statue approach). Hasil penelitian ini adalah perlindungan hukum terhadap hak anak dalam mendapatkan akta kelahiran pada masyarakat telah diatur mulai Undang-Undang Dasar Negara Republik Indonesia Tahun 1945, Undang-Undang Republik Indonesia Nomor 23 Tahun 2002 tentang Pelindungan Anak, Undang-Undang Republik Indonesia Nomor 23 Tahun 2006 yang di ubah dengan Undang-Undang Republik Indonesia Nomor 24 Tahun 2013 tentang Penyelenggaraan Kependudukan, Peraturan daerah Kabupaten Badung Nomor 10 Tahun 2010 yang diubah dengan Perda Kabupaten Badung Nomor 9 Tahun 2016 tentang Perubahan Atas Peraturan Daerah Kabupaten Badung Nomor 10 Tahun 2010 Tentang Penyelenggaraan Administrasi Kependudukan, Peraturan daerah Kota Denpasar Nomor 5 Tahun 2014. Pencatatan Kelahiran yang melampaui batas waktu tetap dapat dilakukan dengan cara meminta persetujuan dari Kepala dinas Kependudukan dan Pencatatan Sipil. Adapun saran dapat diberikan perlu dilakukan sosialisasi terkait dengan tata cara pencatatan kelahiran termasuk tata cara pendaftaran secara online dan perlu melakukan peningkatan pelayanan oleh Pemerintah Daerah. Bagi Masyarakat, perlunya kesadaran dari masyarakat akan pentingnya punya akta kelahiran sebagai wujud hak anak dalam memperoleh akta kelahiran. 


\begin{abstract}
Children's problems lately are very complex. Many cases occur in the community that ignore the fulfillment of children's rights. One is the lack of fulfillment of children's rights on birth certificates. In connection with this matter, it is important to do research to find out 2 (two) things, namely; first, to find out about children's rights in obtaining birth certificates to Balinese indigenous people. Second, to find out whether a child can get a birth certificate if the birth registration goes beyond the deadline. In accordance with the research objectives, the research method used is a normative research method with a statue approach. The results of this study are 1) legal protection of children's rights in obtaining birth certificates in the community has been regulated starting from the 1945 Constitution of the Republic of Indonesia, Law of the Republic of Indonesia Number 23 of 2002 concerning Child Protection, Law of the Republic of Indonesia Number 23 The year 2006 was amended by the Republic of Indonesia Law Number 24 of 2013 concerning the Implementation of Population, Badung Regency Regional Regulation Number 10 of 2010 which was amended by Badung District Regulation Number 9 of 2016 concerning Amendment to Badung Regency Regional Regulation Number 10 of 2010 concerning Implementation Population Administration, Regional Regulation of Denpasar City Number 5 of 2014. 2) Birth Registration that exceeds the fixed time limit can be done by requesting approval from the Head of the Population and Civil Registration Office. The advice can be given 1) socialization is needed regarding the procedures for registering births including procedures for registering online and needing to improve services by the Regional Government. 2) For the community, the need for public awareness of the importance of having a birth certificate as a manifestation of children's rights in obtaining a birth certificate.
\end{abstract}

\section{Latar Belakang}

Anak merupakaan cikal bakal terbentuknya sumberdaya manusia yang handal, tangguh dan berkualitas, kualitas sumberdaya yang tangguh ini sangat ditentukan oleh lingkungan keluarga dan masyarakat memperlakukan anak tersebut, sebagai karunia Tuhan Yang Maha Esa, di dalam diri seorang anak melekat harkat dan martabat sebagai manusia seutuhnya. Oleh karena itu anak sebagai manusia harus mendapat perlindungan oleh Negara, perlindungan seorang anak dapat diartikan sebagai suatu kegiatan untuk menjamin dan melindungi anak berserta hak-haknya agar anak-anak dapat hidup, tumbuh, berkembang dan berpartisipasi secara optimal sesuai harkat dan martabat manusia serta mendapat perlindungan dari kekerasan dan diskriminasi (Kementerian Pemberdayaan Perempuan RI, 2002).
Perlindungan (to protect) terhadap hak anak telah ditetapkan Deklarasi Anak 1979 yang kemudian diadopsi oleh PBB menjadi Konvensi Hak Anak/KHA (Convention on The Rights of The Child) Tahun 1989 dan telah diratifikasi, disetujui atau ditandatangani oleh 192 negara termasuk Indonesia (Asnawi, 2013). Dalam dokumen Internasional mengenai Konvensi hak anak secara jelas diatur mengenai perlindungan anak. Dengan diaturnya hak-hak anak tersebut, Negara wajib melakukan perlindungan dan pemenuhan terhadap hak anak (Ahsinim, 2016).

Berdasarakan ke 31 hak anak di atas, dipahami bahwa hak asasi anak adalah bagian dari hak asasi manusia. Hak asasi manusia secara tegas di muat dalam UUD Negara Republik Indonesia Tahun 1945 dan UU Nomor 39 Tahun 1999 tentang Hak Asasi Manusia. Eksistensi anak dalam kehi- 
dupan bernegara merupakan suatu hal yang sangat penting, mengingat anak merupakan masa depan bagi bangsa dan Negara serta penerus cita-cita bangsa, oleh karena itu keberadaan anak harus mendapat perlindungan baik itu dalam melangsungkan kehidupannya, tumbuh kembangnya serta mendapat perlindungan dari tindak kekerasan.

Pasal 1 angka 1 Undang-Undang Nomor 35 tahun 2014 sebagaimana diubah terakhir dengan UU Nomor 17 Tahun 2016 selanjutnya disebut Undang-Undang Perlindungan Anak, tentang Perlindungan Anak menyebutkan bahwa anak adalah seseorang yang belum berusia 18 tahun termasuk anak yang masih dalam kandungan. Dengan diaturnya definisi konsep anak, seharusnya anak mendapat perlindungan termasuk perlindungan dalam tindak kekerasan, Di sisi lain adanya arahan dari Deputi Kementerian Negara Pemberdayaan Perempuan dan Perlindungan Anak Republik Indonesia menjelaskan adanya kebijakan pengarusutamaan hak anak dalam pembangunan yang digunakan sebagai strategi dalam membangun kebijakan-kebijakan yang berpihak pada hak anak (Reisdian, 2013).

Berdasarkan aspek sosiologis, kerap terjadi tindak kekerasan terhadap anak. Berbagai macam bentuk-bentuk tindak kekerasan terhadap anak diantaranya tindakan kekerasan yang terjadi dikehidupan rumah tangga, sekolah bahkan dalam kehidupan masyarakat. Kekerasan (violence) adalah serangan atau invasi terhadap fisik maupun integritas mental psikologis seseorang (Fakih, 1996).

Ada berbagai macam bentuk kekerasan (violence) terhadap anak yaitu kekerasan fisik, kekerasan Psikis, kekerasan ekonomi/penelantaran, kekerasan seksual) (Mufidah, 2006), selain itu juga dapat dilihat dari apakah hak anak terpenuhi khusunya dalam haknya untuk mendapatkan identitas. Sehingga apabila hak untuk mendapatkan identitas tidak terpenuhi maka dapat dikategorikan kekerasan terhadap anak.
Salah satu bentuk kekerasan terhadap anak adalah tidak terpenuhinya hak untuk mendapatkan identitas. Identitas diri anak yang paling penting adalah indentitas berupa akta kelahiran, akta kelahiran seharusnya sudah diberikan sejak terjadinya kelahiran pada setiap anak. Akta kelahiran merupakan bukti yang sah sebagai bentuk pengakuan dan perlindungan hukum bagi setiap anak. Dapat dipahami bahwa kelahiran merupakan peristiwa hukum yang harus jelas pengaturannya untuk terwujudnya kepastian hukum bagi masyarakat.

Kelahiran seorang anak merupakan suatu peristiwa penting yang harus dicatatkan. Pencatatan kelahiran sangat berkaitan dengan negara, dikarenakan dengan pencatatan kelahiran negara dapat mengetahui pertambahan penduduk sehingga dapat membantu pemerintah dalam membuat aturan dan kebijakan-kebijakan yang berkaitan dengan kependudukan, pentingnya pencatatan kelahiran dikategorikan menjadi 3 (tiga): Mekakukan pencatatan kelahiran merupakan wujud pengakuan secara formal oleh negara mengenai keberadaan seseorang; Pencatatan kelahiran merupakan elemen yang sangat penting dari perencanaan nasional; Dengan pencatatan kelahiran akan memberikan pengamanan dan perlindungan terhadap hak anak.

Melihat pentingnya dilakukan pencatatan kelahiran seorang anak, justru banyak orang tua yang mengabaikan pencatatan kelahiran seorang anak, fakta sosiologis lain adalah masih banyak anak yang tidak mempunyai akta kelahiran. Hal ini dipengaruhi oleh banyak hal diantaranya orang tua yang lalai untuk membuatkan anaknya akta kelahiran, tidak terpenuhinya syarat untuk membuat akte kelahiran sebagaimana kasus yang terdapat di desa Pangsan Kecamatan Petang Kabupaten Badung, beberapa keluarga di Desa Pangsan tidak dapat mengurus akta kelahiran anaknya, dikarenakan orang tuanya tidak memiliki akta perkawinan sebagai syarat untuk mengurus pembuatan akta 
kelahiran. Tidak dapatnya seorang anak mempunyai akta kelahiran dipengaruhi oleh berbagai macam factor seperti factor ekonomi, factor kesadaran orang tua dan lain sebagainya. Sebagamana dipengaruhi oleh factor ekonomi, bahwa tidak semua orang tua mampu untuk membuatkan akte kelahiran dikarenakan ketidakmampuan orang tua untuk membayar biaya pembuatan akta kelahiran. Faktor kesadaran orang tua pun untuk mengurus akta kelahiran secara umum masih rendah. Sehingga berimplikasi pada tidak dapatnya seorang anak untuk mengenyam pendidikan. Berdasarkan paparan di atas dan berdasarkan pada fakta-fakta sosiologis terkait dengan keberadaan anak dengan akta kelahirannya, maka penting untuk diteliti lebih lanjut mengenai Perlindungan Hukum Terhadap Hak Anak Dalam Memperoleh Akta Kelahiran.

\section{Metode}

Metode penelitian yang digunakan dalam penelitian ini adalah metode penelitian normatif atau metode penelitian kepustakaan (Soekanto, 2009). Penelitian hukum norrmatif ditujukan untuk dapat mengungkap persolan hukum yang terdapat di masyarakat dan mencarikan solusi untuk memecahkan permasalahan hukum yang ditemukan. Dalam konteks ini peneliti ingin mengungkap pengaturan yang berkaitan dengan hak anak dalam memperoleh akta kelahiran sebagai bagian dari hak anak.

Sumber bahan hukum yang digunakan adalah sumber bahan hukum primer dan bahan hukum sekunder, bahan hukum primer merupakan bahan hukum yang berupa peraturan perundang-undangan serta putusan hakim. Sedangkan bahan hukum sekunder adalah bahan hukum yang berupa buku, jurnal, makalah yang berkaitan dengan objek penelitian. Bahan hukum sekunder sering disebut sebagai bahan hukum tambahan dan penunjang yang digunakan dalam pemecahan suatu pesoalan.
Berkaitan dengan teknik pengolahan dan analisis dengan menggunakan hermeneutika hukum. Pada tahap pengolahan, bahan hukum primer dan sekunder yang telah terkumpul dikatagorikan dan dikualifikasikan berdasarkan permasalahan yang diajukan. Selanjutnya di susun secara sistematis berdasarkan kerangka yang telah disisiapkan. Bahan hukum tersebut ditafsirkan berdasarkan hermeneutika hukum seingga menghasilkan simpulan hasil dari analisis permasalahan tersebut. Keseluruhan hasil analisis disajikan secara deskriptif yang disertai dengan ulasan-ulasan kritis.

\section{Pembahasan}

1.3. Perlindungan hukum terhadap hak anak dalam mendapatkan akta kelahiran pada masyarakat di kabupaten badung dan kota denpasar

Hak anak tidak dapat dilepaskan dari prinsip-prinsip hak asasi manusia. Memberikan perlindungan terhadap hak anak merupakan aplikasi dari prinsip hak asasi manusia (Komnas HAM, 2017). Oleh Komnas HAM, Prinsip-prinsip HAM berupa;

Pertama, HAM bersifat universal dan tak dapat dicabut (universality and inalienability). Konsep in dipahami bahwa HAM merupakan hak yang melekat pada diri manusia. Hak tersebut tidak apat diserahkan atau dicabut. Pemahaman konsep ini selaras dengan Pasal 1 Deklarasi Umum HAM yang menegaskan bahwa setiap manusia dilahirkan merdeka dan sederajat dalam harkat dan martabatnya. Kedua, HAM tidak bisa dibagi (indivisibility). Ketiga, Dalam Pemenuhan HAM saling bergantung dan berkaitan satu sama lain (interdependence and interrelatedness). Dalam konteks ini pemenuhan HAM terutama pada pemenuhan terhadap hak anak saling berkaitan, sebagai contoh dalam situasi tertentu untuk pemenuhan hak atas pendidikan maka hak untuk mendapatkan informasi tidak dapat terabaikan. Inilah yang menunjukkan bahwa 
hak yang satu saling berkaitan dengan hak yang lain dalam pemenuhan HAM. Keempat, Dalam pemenuhan HAM harus sama dan tanpa diskriminasi (equality and non-discrimination).

Dalam hal equal dan non diskriminasi harus dipandang bahwa setiap individu sederajat dan inheren dalam harkat dan martabatnya masingmasing. Bahawa setiap orang berhak sepenuhnya atas hak-haknya tanpa ada pembedaan dengan alasan apapun, seperti perbedaan ras, warna kulit, jenis kelami etnis, usia, agama dan lain sebagainaya. Kelima, turut berpartisipasi dan berperan aktif (participation and inclusion).

Dalam hal pemenuhan HAM setiap orang termasuk anak harus berpartisipasi dan berkontribusi dalam pembangunan. Keenam, Ada pertanggungjawaban dan penegakkan hukum (accountability and rule of law). Dalam hal ini negara dan para pemangku kebijakan bertanggungjawab untuk mentaati HAM. Negara dan Pemerintah dalam hal ini juga harus tunduk pada norma dan instrumen HAM. Demikian pun dalam hal pemenuhan hak anak, negara dan pemerintah berkewajiban dalam pemenuhan hak anak terutama hak dalam mendapatkan identitas.

Konteks pemenuhan hak anak terhadap akta kelahiran merupakan hak anak yang vital dan wajib dipenuhi oleh ngara, namun hal yang berbeda dikemukakan oleh Komisi Perlindungan Anak Indonesia (KPAI), antara tahun 2010-2013 yang menunjukan bahwa rendahnya penghormatan, pemenuhan dan perlindungan terkait dengan hak sipil dan kebebasan anak. Permasalahan yang dominan muncul pada anak adalah hak atas nama, kewarganegaraan, hak mempertahankan identitas, hak kebebasan menyatakan pendapat dan hak akses terhadap informasi yang layak. Hal ini dapat dipahami bahwa ada pengabaian terhadap hak anak dalam mendapatkan identitas.

Beberapa peraturan yang mengatur mengenai hak anak untuk mendapatkan indentitas diri (akta kelahiran). Sebagaimana ditegaskan dalam
Pasal 27 UU 35 Tahun 2014 yang menegaskan: (1) setiap anak yang lahir harus diberikan identitas diri; (2) Identitas tersebut harus dituangkan ke dalam akta kelahiran. Dengan demikian pemahaman Pasal 27 UU 35 Tahun 2014 jelas dimaknai bahwa setiap ada kelahiran anak, maka seorang anak berhak untuk dibuatkan identitas, termasuk akta kelahiran.

Pencermatan Pasal 28 ayat (4) UU 35 Tahun 2014, bahwa dalam membuat akta kelahiran tidak dikenakan biaya. Selanjutnya dalam ayat (5) diatur mengenai tata cara pembuatan akta kelahiran dilaksanakan sesuai dengan peraturan perundangundangan. Ketentuan yang sama juga terdapat dalam Pasal 79 A UU No 24 Tahun 2013 tentang Perubahan Atas Undang-Undang Nomor 23 Tahun 2013 Tentang Administrasi Kependudukan. Dalam Pasal ini jelas ditentukan bahwa dalam pengurusan dan penerbitan Dokumen Kependudukan tidak dipungut biaya.

Pengaturan mengenai tata cara mendapatkan akta kelahiran juga diatur dalam Peraturan Menteri Dalam Negeri No 9 Tahun 2016 tentang Percepatan Peningkatan Cakupan Kepemilikian Akta Kelahiran. Peraturan Menteri Dalam Negeri No 9 Tahun 2016 dimaknai bahwa negara wajib memberikan perlindungan dan pengakuan terhadap penentuan status pribadi dan status hukum setiap peristiwa kelahiran yang merupakan hak anak dengan bentuk dikeluarkannya akta kelahiran. Dikarenakan memiliki akta kelahiran merupakan hak maka selayaknya setiap anak memiliki akta kelahiran tanpa kecuali.

Dasar pemikiran dikeluarkannya Peraturan Menteri Dalam Negeri No 9 Tahun 2016 tentang Percepatan Peningkatan Cakupan Kepemilikian Akta Kelahiran ini dikarenakan masih rendahnya kepemilikan akta kelahiran bagi setiap anak dan masih rendahnya pelayanan pemerintah dalam proses pembentukan akta kelahiran. Dengan alasan ini maka pada tahun 2016 di keluarkan Peraturan Menteri Dalam Negeri No 9 Tahun 2016 tentang 
Percepatan Peningkatan Cakupan Kepemilikian Akta Kelahiran sebagai wujud pengakuan negara atas identitas anak dalam bentuk akta kelahiran. Mengenai persyaratan dan tatacara pencatatan kelahiran jelas telah diatur dalam Peraturan Menteri Dalam Negeri No 9 Tahun 2016.

Berkaitan dengan hak anak dalam mendapatkan akta kelahiran sebagai bentuk perlindungan hukum terhadap hak anak di Kota Denpasar adalah telah diaturnya hak anak dalam mendapatkan akta kelahiran dalam Perda Kota Denpasar Nomor 5 Tahun 2014 tentang Penyelenggaraan Administrasi Kependudukan. Pasal 6 Perda No 5 Tahun 2014 ditentukan bahwa salah satu kewajiban Pemerintah Kota Denpasar adalah menerbitkan akta kelahiran. Selanjutnya dalam Pasal 47 Perda No 5 Tahun 2014 ditegaskan bahwa setiap peristiwa kelahiran di catatkan di Dinas Kependudukan dan Pencatatan Sipil. Mengenai tata cara pencatatan kelahiran diatur dengan Peraturan Bupati. Dalam Pasal 47 juga ditegaskan bahwa dalam melakukan pencatatan kelahiran tidak dipungut biaya.

Menarik untuk dicermati terkait dengan pembuatan akta kelahiran yang tidak dipungut biaya dan sudah berlaku pendaftaran dengan sistem online sebagaimana diatur dalam Peraturan Menteri Dalam Negeri No 9 Tahun 2016. Dalam konteks ini dapat dicermati bahwa di dalam Perda Kota Denpasar No 5 Tahun 2014 belum diatur mengenai pendaftaran akta kelahiran secara online, hal ini berdampak pada pengabaian hak anak dalam mendapatkan akta kelahiran. Dampak yang ditimbulkan adalah masyarakat masih kebingungan dalam mendaftarkan kelahiran anaknya.

Apabila akta kelahiran merupakan hak dari seorang anak, maka Pemerintah Daerah wajib untuk menerbitkan akta kelahiran. Di dalam kewajiban pemerintah daerah dalam menerbitkan akta kelahiran seorang anak, Pemerintah wajib membuat tatacara dan strategi baik secara online maupun manual untuk pendaftaran akta kelahiran. Dengan demikian tidak ada alasan bagi warga Kota
Denpasar tidak memiliki akta kelahiran. Inilah yang menjadi problem dalam pelaksanaan pencatatan kelahiran. Bahwa belum diatur pendaftaran online dalam Perda Kota Denpasar No 5 Tahun 2014 menyebabkan terhambatnya atau berdampak pada pengabaian hak anak untuk mendapatkan akta kelahiran.

Berkaitan dengan pengaturan pencatatan kelahiran di Kabupaten Badung juga telah diatur dalam Perda Kabupaten Badung No 9 Tahun 2016 tentang Perubahan Atas Peraturan Daerah Kabupaten Badung Nomor 10 Tahun 2010 Tentang Penyelenggaraan Administrasi Kependudukan. Peristiwa kelahiran merupakan peristiwa penting yang wajib untuk dilaporkan kepada pemerintah dan dicatatkan. Kepemilikan akta kelahiran bagi seseorang merupakan data kependudukan yang wajib dimiliki. Hal ini sebagaimana diatur dalam Pasal 46 Perda Kabupaten Badung No 9 Tahun 2016 tentang Perubahan Atas Peraturan Daerah Kabupaten Badung Nomor 10 Tahun 2010 Tentang Penyelenggaraan Administrasi Kependudukan. Pengaturan secara rinci mengenai peristiwa kelahiran di atur dalam Pasal 22 Perda Kabupaten Badung No 9 Tahun 2016 tentang Perubahan Atas Peraturan Daerah Kabupaten Badung Nomor 10 Tahun 2010 Tentang Penyelenggaraan Administrasi Kependudukan yang menentukan bahwa setiap peristiwa kelahiran wajib dilakukan pencatatan oleh Dinas Kependudukan dan Catatan Sipil. Menarik untuk dicermati Pasal 73 A Perda Kabupaten Badung No 9 Tahun 2016 tentang Perubahan Atas Peraturan Daerah Kabupaten Badung Nomor 10 Tahun 2010 Tentang Penyelenggaraan Administrasi Kependudukan yang menentukan bahwa kepengurusan dan penerbitan akta kelahiran tidak dipungut biaya.

Penormaan dalam Pasal 73 A ini merupakan cerminan kewajiban Pemerintah daerah Kabupaten Badung dalam memenuhi hak atas akta kelahiran anak. Melakukan kewajiban pemerintah daerah Kabupaten Badung berkaitan dengan pencatatan 
kelahiran harus menyesuaikan dengan tata cara pencatatan kelahiran. Mengenai tata cara pencatatan kelahiran sebagaiaman diatur dalam Pasal 6 Perda Kabupaten Badung No 9 Tahun 2016 tentang Perubahan Atas Peraturan Daerah Kabupaten Badung Nomor 10 Tahun 2010 Tentang Penyelenggaraan Administrasi Kependudukan disesuaikan dengan peraturan perundang-undangan. Hal ini menjadi problem ketika pelaksanaan tata cara pencatatan kelahiran, problemnya terletak pada kejelasan mengenai tata cara pencatatan kelahiran, seharusnya ada Peraturan Bupati yang mengatur lebih lanjut tentang tata cara teknis pencatatan kelahiran.

Berkaitan dengan tata cara dan syarat pencatatan kelahiran telah diatur dalam Pasal 51 sampai dengan Pasal 54 Peraturan Presiden Nomor 25 Tahun 2008 tentang Persyaratan dan Tata cara Pendaftaran Penduduk dan Pencatatan Sipil. Salah satu inovasi tata cara pencatatan kelahiran seorang anak yang dilakukan oleh Pemerintah daerah Badung adalah dengan adanya penandatanganan nota kesepahaman (MoU) tentang pembuatan akta kelahiran antara RSUD Mangusada Badung dengan Dinas Kependudukan dan Catatan Sipil Kabupaten Badung, yang pada intinya seorang anak yang lahir dan besoknya seorang anak mengantongi akte kelahiran, nomor induk kependudukan (NIK), termasuk perubahan kartu keluarga (KK). Namun hal ini dapat dikritisi mengingat tidak semua penduduk memiliki persyaratan dalam mengurus akta kelahiran anak seperti akta perkawinan orang tuanya dan nama nak itu sendiri. Sehingga peran pemerintah daerah yang sangat baik dan progresif ini, tiba tiba menjadi kendala bagi masyarakat itu sendiri. Seperti misalnya dalam penyiapan nama dan pemberian nama bagi seorang anak pada masyarakat adat Bali memerlukan upacara dan sesuai dengan adat istiadatnya, sehingga ini juga yang menjadi kendala dalam mewujudkan inovasi penerbitan akta kelahiran di Kabupaten Badung.

Dengan demikian dapat dipahami bahwa dalam penerbitan akta kelahiran sebagai hak seorang anak perlu mengharmoniskan inovasi yang dikeluarkan oleh Pemerintah Daerah Kabupaten Badung dengan adat dan budaya masyarakat Bali, sehingga dalam rangka pemenuhan hak atas akta kelahiran tidak menjadi beban dan kendala bagi masyarakat itu sendiri. Singkatnya untuk mendukung inovasi dalam pencatatan kelahiran di Kabupaten Badung perlu dibuat tata cara dan syarat pencatatan kelahiran yang tidak saja berdasarkan pada tata cara yang telah diatur dalam peraturan perundangundangan namun perlu juga memperhatikan adat dan budaya masyarakat Bali yang berhubungan dengan pemberian nama pada seorang anak.

1.4. Pencatatan akta kelahiran yang melampui batas waktu

Konteks pencatatan kelahiran, negara harus proaktif dalam pemenuhan hak identitas anak, bukan menghukum datau memberikan sanksi apabila dalam pencatatan kelahiran tersebut sampai melewati batas waktu yang telah ditentukan. Negara dalam konteks pemenuhan hak identitas terhadap anak dimaknai bahwa negara berkewajiban dalam mengeluarkan akta kelahiran bagi setiap kelahiran seorang anak. Berbeda ketika memahami Penjelasan umum UU Nomor 23 Tahun 2006 yang menegaskan bahwa dalam melakukan pendaftaran penduduk pada dasarnya menganut stelsel aktif yaitu membebankan kewajiban pada penduduk untuk mendaftarkan atau mencatatkan peristiwa penting, termasuk kewajiban penduduk dalam mencatatkan setiap kelahiran. Hal ini dipahami bahwa dalam pencatatan kelahiran seolah-olah bukan kewajiban negara. Hal ini tentu saja bertentangan dengan konstitusi dimana setiap anak berhak dalam mendapatkan identitas.

Di sisi lain perlindungan terhadap hak untuk mendapatkan akta kelahiran yang masa pencatatan kelahiran melampaui batas waktu diatur dalam Pasal 32 UU Nomor 23 Tahun 2006 tentang penyelenggaraan kependudukan, yang menegaskan bahwa pelaporan kelahiran yang melampaui batas waktu 60 hari sampai dengan 1 tahun maka pen- 
catatan kelahiran dilaksanakan dan mendapat persetujuan Kepala Instansi Pelaksana. Selanjtnya dalam ayat (2) dijelaskan bahwa apabila pencatatan kelahiran melampaui batas waktu 1 tahun, pencatatan kelahiran dilaksanakan dengan penetapan pengadilan.

Berkaitan dengan pemahaman stelsel aktif dan pencatatan kelahiran yang melampaui batas waktu 1 Tahun harus dengan penetapan pengadilan dirasakan cukup berat oleh masyarakat. Keberatan masyarakat dalam pengurusan akta kelahiran seperti ini, berdampak pada kurangnya niat masyarakat untuk mengurus akta kelahiran anak, sehingga banyak anak yang tidak memiliki akta kelahiran sebagai bentuk identitas seorang anak. Hal ini banyak terjadi pada anak-anak yang berada di daerah terpencil atau di desa-desa terpencil.

Selanjutnya, dengan dikeluarkannya surat edaran Mahkamah Agung Nomor 06 Tahun 2012 tentang Pedoman Penetapan Pencatatan Kelahiran yang melampaui batas waktu satu tahun secara kolektif, menunjukan adanya kepedulian negara bahwa pemenuhan hak atas identitas anak merupakan HAM. Dalam ketentuan tersebut dipahami bahwa anak-anak yang lahir setelah UU nomor 23 Tahun 2006 dan belum mengurus akta kelahiran maka dapat dilayani dan diterbitkan akta kelahirannya tanpa penetapan pengadilan. Hal ini merupakan angin segar bagi masyarakat dalam mengurus akta kelahiran. Penguatan mengenai pencatatan kelahiran yang melampuai batas waktu ditentukan dalam ketentuan Pasal 32 UU 24 Tahun 2013 tentang Perubahan Atas Undang-Undang Nomor 23 Tahun 2006 tentang Administrasi Kependudukan. Dalam Pasal 32 UU 24 Tahun 2013 ditegaskan pelaporan kelahiran yang melampaui batas waktu 60 hari sejak tanggal kelahiran, maka pencatatan dan penerbitan Akta Kelahiran dilaksanakan setelah mendapat keputusan Kepala Instansi Pelaksana setempat.

Pasal 49 ayat (2) UU 24 Tahun 2013 yang menyatakan bahwa pengakuan anak hanya berlaku bagi anak yang orang tuanya telah melangsungkan perkawinan yang sah berdasarkan hukum agama. Hal ini dipahami bahwa seorang anak baru mendapat pengakuan apabila orang tuanya telah melakukan perkawinan sah menurut hukum agama dan catatan sipil menerbitkan kutipan akta kelahiran. Penegasan Pasal 49 UU 24 Tahun 2013, tampaknya memberikan dampak ketidakadilan bagi seorang anak yang lahir tanpa di dahului suatu perkawinan yang sah. Dalam konteks ini pengakuan terhadap anak hanya di peroleh oleh seorang anak yang lahir dari perkawinan yang sah.

Pengaturan pencatatan kelahiran yang melampaui batas waktu juga ditegaskan dalam Peraturan Daerah Kota Denpasar Nomor 5 Tahun 2014 tentang Penyelenggaraan Administrasi Kependudukan. Berkaitan dengan pengaturan pencatatan kelahiran yang melampaui batas waktu, dengan tegas diatur dalam Pasal 47 ayat (5) yang menentukan bahwa Pencatatan pelaporan kelahiran yang melampaui batas waktu 60 hari sejak tanggal kelahiran maka pencatatan kelahiran harus mendapat persetujuan Kepala Dinas Kependudukan dan Pencatatan Sipil.

Pencatatan kelahiran baik itu pencatatan yang tepat waktu atau pencatatana kelahiran yang melampaui batas waktu tidak dipungut biaya. Ketentuan yang sama terdapat dalam Pasal 22 Perda Kabupaten Badung Nomor 9 Tahun 2016 yang menentukan bahwa pencatatan kelahiran yang melampaui batas waktu tidak lagi melalui penetapan pengadilan melainkan hanya perlu mendapatkan persetujuan Kepala Dinas Kependudukan dan Catatan Sipil. Mengenai pencatatan kelahiran baik yang tepat waktu maupun yang melampaui batas waktu tidak dipungut biaya.

Berdasarkan pemahaman pengaturan di atas, jelas bahwa pencatatan kelahiran yang melampaui batas waktu dan cukup mendapatkan persetujuan Kepala Dinas Kependudukan dan Catatan Sipil serta tidak dipungut biaya merupakan cerminan dan penjabaran dari HAM. Dalam Konsti- 
tusi hak untuk mendapatkan identitas diatur dalam Pasal 28 D ayat (1) UUD NRI Tahun 1945 menegaskan setiap orang berhak atas pengakuan, jaminan, perlindungan, dan kepastian hukum yang adil serta perlakuan yang sama di hadapan hukum". Selanjutnya dalam Pasal 28 D UUD RI Tahun 1945 menegaskan bahwa setiap orang berhak atas status kewarganegaraan. Hal ini dipahami bahwa setiap orang dalam hal ini anak berhak untuk mendapat hak atas identitas termasuk hak atas akta kelahiran. Hal ini secara yuridis memberi arahan bahwa negara harus memenuhi hak atas akta kelahiran, termasuk Pemerintah Kota Denpasar dan Kabupaten Badung. Namun ada pertanyaan yang menggelitik, apakah dengan diatur secara jelas mengenai pencatatan kelahiran yang melampui batas waktu, membuat masyarakat sadar untuk melaporkan peristiwa kelahiran yang terjadi. Hal ini perlu dilakukan kajian mengenai perilaku masyarakat terhadap pencatatan kelahiran yang melampaui batas waktu. Dasar Pemikiran ini timbul dikarena ada data yang menunjuk bahwa $18 \%$ penduduk di Indonesia tanpa akta kelahiran (Islahuddin, 2017).

\section{Simpulan}

Perlindungan hukum terhadap hak anak dalam mendapatkan akta kelahiran pada masyarakat sudah diatur melalui Konvensi Internasional mengenai Konvensi Hak Anak, UUD NRI Tahun 1945, UU Nomor 23 Tahun 2002 yang diubah dengan UU 35 Tahun 2014 dan terakhir diatur dengan UU 17 Tahun 2016 tentang Penetapan Peraturan Pemerintah Penganti UU Nomor 1 Tahun 2016 tentang Perubahan Kedua Atas UU 23 Tahun 2002 Tentang Perlindungan Anak menjadi UU. Perlindungan hukum terhadap hak anak untuk mendapatkan akta kelahiran juga dapat dilihat dalam UU 23 Tahun 2006 tentang Administrasi Kependudukan yang selanjutnya di ubah dengan UU 24 Tahun 2013. Pengaturan mengenai pencatatan kelahiran juga diatur dalam peraturan Menteri Dalam
Negeri Tanggal 9 Tahun 2016 tentang Percepatan Peningkatan Cakupan Kepemilikan Akta kelahiran. Pada tingkat Daerah hak untk mendapatkan akta kelahiran diatur dalam Perda Kabupaten Badung Nomor 10 Tahun 2010 tentang Penyelenggaraan Administrasi Kependudukan sebagaimana telah diubah dengan Perda Kabupaten Badung Nomor 9 Tahun 2016 tentang Perubahan Atas Peraturan Daerah Kabupaten Badung Nomor 10 Tahun 2010 Tentang Penyelenggaraan Administrasi Kependudukan.

Pencatatan Kelahiran yang melampaui batas waktu tetap dapat dilakukan dengan cara meminta persetujuan dari Kepala dinas Kependudukan dan Pencatatan Sipil sebagaimana diatur dalam Surat Edaran Menteri Dalam Negeri RI No. 472.ii/ 34444/SJ yang berkaitan dengan anak-anak berhak mendapatkan akta kelahiran tanpa penetapan pengadilan yang melampaui batas waktu. Surat Edaran MA Nomor 06 Tahun 2011 tentang Pedoman Pencatatan Kelahiran yang melampaui batas waktu satu tahun secara kolektif.

\section{Daftar Pustaka}

Ahsinim, Adzkar. 2016. Anak Sebagai Korban Paling awal dan Paling Rentan Karena Tindakan Diskriminatif Yayasan Pemantau Hak Anak: Children"s Human Rights Foundation. Jakarta. diaksestanggal 17 Mei 2016.

Asnawi, Habib Shulton. 2013. Politik Hukum Puusan MK No. 46/PUU-VIII/2010 Tentang Status Anak di Luar Nikah: Upaya Membongkar Positivisme Hukum Menuju Perlindungan HAM. Jakarta. Jurnal Konstitusi, Vol. 10, Nomor 2, Juni 2013.

Emi, Daly. 1999. Kajian Implementasi Peraturan Perundangundangan dalam Hal Pembuatan Akta Kelahiran. (laporan Penelitian Depok).

Fakih, Mansour. 1996. Analisis gender \& Transformasi Sosial. Yogyakarta. Pustaka Pelajar.

Gosita, Arif. 1985. Masalah Perlindungan Anak. Jakarta. Akademika Pressindo.

Hayati, Nur. 2014. Perlindungan Anak terhadap Kejahatan Kekerasan Seksual (pedofilia). Jurnal Ragam 


\section{Jurnal Cakrawala Hukum I Volume 9 No. 1 Juni 2018}

ISSN PRINT 2356-4962 ISSN ONLINE 2598-6538

Jurnal Pengembangan Humaniora, Vol. 14. No.1 April 2014.

Islahuddin. 2017. Meski Gratis, 18 persen penduduk tanpa akta kelahiran." https://beritagar.id. publish Kamis, 28 September 2017.

Kementerian Pemberdayaan Perempuan RI. 2002. Analisis Undang-Undang Republik Indonesia No.23 Tahun 2002 tentang Perlindungan Anak. Jakarta.

Mertokusumo, Sudikno. 2002. Hukum Acara Perdata Indonesia. Yogyakarta. Liberty.

Mufidah Ch. at.al. 2006. Haruskah Perempuan dan Anak Dikorbankan, Panduan Pemula untuk Pendampingan Korban Kekerasan Terhadap Perempuan dan Anak. Malang. Pilar Media.

Peraturan Daerah Kabupaten Badung Nomor 10 Tahun 2010 Tentang Penyelenggaraan Administrasi Kependudukan sebagaimana telah diubah dengan Peraturan Daerah Kabupaten Badung Nomor 9 Tahun 2016 Tentang Perubahan Atas Peraturan Daerah Kabupaten Badung Nomor 10 Tahun 2010 Tentang Penyelenggaraan Administrasi Kependudukan.

Peraturan Daerah Kota Denpasar Nomor 5 Tahun 2014 Tentang Penyelenggaraan Administrasi Kependudukan.

Peraturan Darah Kabupaten Badung Nomor 9 Tahun 2016 tentang Perubahan Atas Peraturan Daerah Kabupaten Badung Nomor 10 Tahun 2010 Tentang Penyelenggaraan Administrasi Kependudukan.

Peraturan Menteri Dalam Negeri Nomor 9 Tahun 2016 Tentang Percepatan Peningkatan Cakupan Kepemilikan Akta Kelahiran.

Peraturan Pemerintah Nomor 37 Tahun 2007 Tentang Pelaksanaan Undang-Undang Nomor 23 Tahun 2006 Tentang Administrasi Kependudukan sebagaimana diubah dengan Peraturan Pemerintah Nomor 102 Tahun 2012 Tentang Perubahan Atas Peraturan Pemerintah Nomor 37 Tahun 2007 Tentang Pelak- sanaan Undang-Undang Nomor 23 Tahun 2006 Tentang Administrasi Kependudukan.

Peraturan Presiden Nomor 25 Tahun 2008 Tentang Persyaratan Dan Tata Cara Pendaftaran Penduduk Dan Pencatatan Sipil.

Putusan Makamah Konstitusi Nomor Nomor 18 /PUU$\mathrm{XI} / 2013$.

Reisdian, Rangga, at.al. 2013. Implementasi Kebijakan Pengarusutamaan Hak Anak Dalam Rangka Mewujudkan Kabupaten Layak Anak (Studi pada Badan Pemberdayaan Perempuan dan Keluarga Berencana Kabupaten Jombang). Malang. Jurnal Administrasi Publik (JAP), Vol. 1. No.16.

Soekanto, Soerjono. at.al. 2009. Penelitian Hukum Normatif Suatu Tinjauan Singkat. Cetakan ke - 11. Jakarta. Raja Grafindo Persada.

Susilowati, Diah. 2006. Aspek Hukum Perlindungan Anak, Jakarta. Jurnal Konstitusi, Volume 3 Nomor 2, Mei 2006.

Undang Undang Dasar Negara Republik Indonesia Tahun 1945.

Undang-Undang Nomor 23 Tahun 2002 tentang Perlindungan Anak Sebagaimana diubah terakhir dengan Undang-Undang 17 Tahun 2016 tentang Penetapan Peraturan Pemerintah Pengganti UndangUndang Nomor 1 Tahun 2016 Tentang Perubahan Kedua Atas Undang-Undang Nomor 23 Tahun 2002 tentang Perlindungan Anak Menjadi UndangUndang.

Undang-Undang Nomor 23 TAhun 2006 Tentang Administrasi Kependudukan sebagaimana diubah dengan Undang-Undang Nomor 24 Tahun 2013 Tentang Perubahan Atas Undang-Undang Nomor 23 Tahun 2006 Tentang Administrasi Kependudukan.

Undang-Undang Nomor 39 Tahun 1999 tentang Hak Asasi Manusia. 